\title{
Association of abnormal fibrin polymerisation with severe liver disease
}

\author{
G. GREEN'1, L. POLlER, JEAN M. THOMSON, AND I. W. DYMOCK
}

From the Departments of Medicine and Haematology, University Hospital of South Manchester, Manchester

SUMMARY The frequent occurrence of abnormal fibrin polymerisation in patients with liver disease has recently been reported. To investigate this further, fibrin polymerisation was studied in 68 patients with cirrhosis or chronic active liver disease. Thirty-three of these patients demonstrated impairment of this phase of blood coagulation. When other tests of liver function were compared in patients demonstrating this abnormality and those in whom fibrin polymerisation was normal, it was found that the former group demonstrated significantly reduced albumin concentrations $(P<0.0002)$, raised bilirubin and aspartate aminotransferase levels $(\mathrm{P}<0.0006$ and $<0.003$ respectively), and greater prolongation of the one-stage prothrombin time $(\mathrm{P}<0.001)$ with more marked reduction in factor VII levels $(\mathrm{P}<0.002)$ compared with the latter patients. It is concluded that defective fibrin polymerisation occurring in patients with liver disease indicates the presence of severely impaired hepatocellular function. This might account for the grave prognosis reported in cirrhotic patients with abnormal fibrin polymerisation who also suffer bleeding from gastro-oesophageal varices.

Among the many abnormalities of blood coagulation in patients with liver disease, delayed conversion of fibrinogen to fibrin clot under the influence of thrombin is a common laboratory finding. Evidence has been presented to implicate a disturbance of fibrin polymerisation in these patients as a cause of the prolonged thrombin time (Von Felten et al., 1969; Soria et al., 1970; Aiach et al., 1973; Barr et al., 1976; Green et al., 1976a).

The incidence of abnormal fibrin polymerisation has been shown to be as high as $50 \%$ in advanced cirrhosis, $47 \%$ in chronic liver disease, and $100 \%$ in patients with acute liver failure (Green et al., 1975). This contrasts with its infrequency in obstructive jaundice and secondary liver disease (Green et al., 1976a).

It has also been shown that haemorrhage from gastro-oesophageal varices carries a particularly high mortality in cirrhotic patients who also exhibit

\footnotetext{
${ }^{1}$ Address for correspondence: Dr G. Green, USC Liver Unit, Rancho Los Amigos Hospital, Downey, California 90242, USA.
}

Received for publication 15 March 1977 this defect of fibrin polymerisation (Green et al. 1976a).

In an attempt to clarify the implications of this clotting abnormality, fibrin polymerisation was investigated in a group of patients with either cirrhosis or chronic active liver disease. Comparison was made with other laboratory tests of liver function on those who demonstrated this acquired form of 'dysfibrinogenaemia' and those who did not.

\section{Methods}

Fibrin polymerisation was studied in 48 patients with cirrhosis, 20 with chronic active liver disease, and 34 normal control subjects. Serum albumen and globulin concentration, bilirubin estimation, alkaline phosphatase, aspartate aminotransferase, one-stage prothrombin time, fibrinogen concentration (Ingram and Matchett, 1960), and factor VII assays (Poller et al., 1971) were also performed in most cases.

\section{FIBRIN POLYMERISATION}

This was measured by a colorimetric technique (Soria et al., 1969) modified as follows: plasma was diluted in $0.15 \mathrm{M} \mathrm{NaCl}$, according to the fibrinogen 
level measured to give a fibrinogen concentration of $0.6 \mathrm{~g} / 1$. Reptilase $2(0.1 \mathrm{ml})$ was added to $2.5 \mathrm{ml}$ of the diluted plasma in a colorimeter tube. The initial optical density reading was adjusted for each patient to compensate for any colour or turbidity differences-for example, hyperbilirubinaemia. The increase in the change in optical density with time was recorded. As all control plasmas had reached a maximal optical density change by 10 minutes, it was this reading, termed the $\mathrm{H}_{10}$ value, which was chosen to compare fibrin polymerisation in the controls and patients. Any impairment of polymerisation of fibrin after adding Reptilase to the diluted plasma would be reflected by a corresponding reduction in the optical density of the clot formed at the 10-minute mark-that is, $\mathrm{H}_{10}$ value.

All results were compared using Student's $t$ test for unpaired samples.

\section{Results}

\section{FIBRIN POLYMERISATION}

The Figure illustrates the optical density readings at 10 minutes $\left(\mathrm{H}_{10}\right.$ values) recorded in the control subjects and 68 patients with primary liver disease. As the $\mathrm{H}_{10}$ values of the controls were in an approximately Gaussian distribution, the normal range for this value was based on the mean \pm 2 standard deviations. An $\mathrm{H}_{10}$ value falling below the lower level of this normal range was considered to indicate the presence of abnormal fibrin polymerisation (Green et al., 1976a).

The mean $\mathrm{H}_{10}$ value for the 34 controls was 0.665 units (SD 0.15), giving a lower limit of 0.365 units for the $\mathrm{H}_{10}$ range.

As observed in the Figure, the mean $\mathrm{H}_{10}$ value for the 68 patients of 0.385 units was significantly less than the controls $(P<0.001)$. Thirty-three were considered to exhibit severe impairment of fibrin polymerisation by the defined criteria, an incidence of $48.5 \%$ in this group. For the purposes of further comparison the 35 patients with normal fibrin polymerisation were used as a 'contrast' group for comparison with the 33 patients in whom this process was abnormal.

OTHER LABORATORY TESTS OF LIVER

FUNCTION

The Table summarises the results of the two groups studied.

\section{Serum albumin}

Twenty-one of the patients with abnormal fibrin polymerisation had hypoalbuminaemia, compared

2Paines and Byrne Ltd, Pabyrn Laboratories, Greenford, Middlesex, Great Britain.

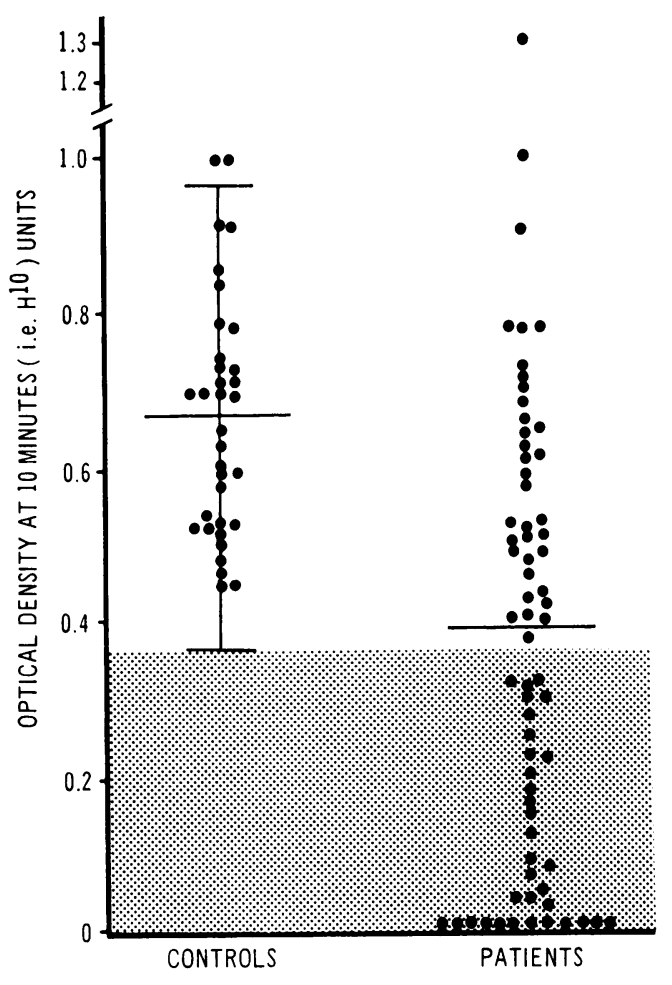

Figure Optical density readings at 10 minutes $\left(\mathrm{H}_{10}\right)$ in the fibrin polymerisation test for controls and patients. (Stippled area indicates abnormal range).

with six patients in the contrast group. The mean albumen level of $29.8 \mathrm{~g} / \mathrm{l}$ in the former was significantly less than that of $35.9 \mathrm{~g} / \mathrm{l}$ in the latter group $(\mathrm{P}<0.0002)$.

\section{Serum globulin}

Nineteen patients with abnormal fibrin polymerisation had hyperglobulinaemia, compared with 13 of the contrast group. There was no significant difference between the mean levels of the two groups.

\section{Serum bilirubin}

Twenty-eight of the patients with impaired fibrin polymerisation had raised bilirubin levels. Only 19 of the contrast group had a similar biochemical abnormality. The mean bilirubin level of the former was $120.7 \mu \mathrm{mol} / \mathrm{l}(7.0 \mathrm{mg} / 100 \mathrm{ml})$ and of the latter group $25.9 \mu \mathrm{mol} / \mathrm{l}(1.5 \mathrm{mg} / 100 \mathrm{ml})$, which were highly significantly different $(\mathrm{P}<0.0006)$.

\section{Alkaline phosphatase}

The two groups showed no significant difference between their mean levels, 22 of the contrast group 
Table Mean values $( \pm S E M)$ for various indices of liver function in patients with normal and impaired fibrin polymerisation

\begin{tabular}{|c|c|c|c|c|c|c|}
\hline \multirow[t]{2}{*}{ Investigation } & \multicolumn{2}{|c|}{$\begin{array}{l}\text { Normal fibrin } \\
\text { polymerisation }\end{array}$} & \multicolumn{2}{|c|}{$\begin{array}{l}\text { Abnormal fibrin } \\
\text { polymerisation }\end{array}$} & \multirow[t]{2}{*}{$\begin{array}{l}\text { Hospital } \\
\text { normal range }\end{array}$} & \multirow[t]{2}{*}{ Significance } \\
\hline & No. studied & $M e a n \pm 1 S E M$ & No. studied & $M e a n \pm 1 S E M$ & & \\
\hline $\begin{array}{l}\text { Serum albumen }(\mathrm{g} / \mathrm{l}) \\
\text { Serum globulin }(\mathrm{g} / \mathrm{l}) \\
\text { Serum bilirubin }(\mathrm{pmol} / \mathrm{l}) \\
\text { Alkaline phosphatase (IU/I) } \\
\text { Aspartate amino-transferase (IU/I) } \\
\text { Fibrinogen (g/I) } \\
\text { Prothrombin time(s) } \\
\text { Factor VII activity (\%) }\end{array}$ & $\begin{array}{l}35 \\
35 \\
35 \\
35 \\
35 \\
35 \\
32 \\
28\end{array}$ & $\begin{array}{r}35.09 \pm 0.99 \\
37.06 \pm 1.37 \\
25.86 \pm 2.94 \\
299.05 \pm 64.5 \\
87.00 \pm 10.6 \\
2.05 \pm 0.074 \\
14.05 \pm \\
77.00 \pm 4.08\end{array}$ & $\begin{array}{l}32 \\
32 \\
32 \\
32 \\
32 \\
33 \\
32 \\
31\end{array}$ & $\begin{array}{c}29 \cdot 8 \pm 1 \cdot 00 \\
39 \cdot 16 \pm 1 \cdot 74 \\
120 \cdot 72 \pm 26 \cdot 2 \\
225 \cdot 5 \pm 54 \cdot 2 \\
166 \cdot 2 \pm 22 \cdot 8 \\
2 \cdot 24 \pm 0.098 \\
19 \cdot 0 \pm 1 \cdot 25 \\
51.0 \pm 5.06\end{array}$ & $\begin{array}{l}32-46 \\
21-38 \\
3-19 \\
28-121 \\
6-50 \\
1-3 \\
11-13 \\
80\end{array}$ & $\begin{array}{l}<0.0002 \\
\text { NS } \\
<0.0006 \\
\text { NS } \\
<0.003 \\
<0.05 \\
<0.001 \\
<0.002\end{array}$ \\
\hline
\end{tabular}

SEM : standard error of the mean. NS: Not Significant

and 19 of the patient group demonstrating raised levels (Table).

\section{Aspartate aminotransferase}

The mean level of $166 \cdot 2 \mathrm{IU} / \mathrm{l}(166 \cdot 2 \mathrm{KU})$ in the patients with abnormal fibrin polymerisation was significantly higher than that of the contrast group of $87.0 \mathrm{IU} / 1(87.0 \mathrm{KU})(\mathrm{P}<0.003)$, all but three of the former group showing markedly raised levels compared with only 22 of the contrast patients.

\section{Plasma fibrinogen}

All patients had normal levels. However, the mean of $2.24 \mathrm{~g} / 1$ for the patients with the polymerisation abnormality was significantly less than that of the contrast group of $2.5 \mathrm{~g} / 1(\mathrm{P}<0.05)$. Possible causes of this discrepancy are discussed later.

\section{Prothrombin time}

Twenty-one of 32 patients with impaired fibrin polymerisation had prolonged one stage prothrombin times, the mean for the group being 19.0 seconds. Nineteen of the contrast group also had prolonged prothrombin times, the mean of 14.5 seconds being significantly less than that of the patient group $(\mathrm{P}<0.001)$.

\section{Factor VII activity}

Specific Factor VII activity also differed between the two groups, 23 of 31 patients with impaired polymerisation having reduced levels (mean $51.0 \%$ ). Only 11 of 28 contrast patients had such a reduction, their mean of $77 \%$ being significantly greater $(\mathrm{P}<0.002)$.

\section{Discussion}

Conversion of fibrinogen to fibrin clot under the influence of thrombin is the final stage of blood clotting. The recent reports of a severe disturbance of this process in a high proportion of patients with liver disease (Green et al., 1975, 1976a; Barr et al., 1976) appears to be of importance. Its association with haemorrhage from gastro-oesophageal varices has also been reported to signify a poor prognosis (Green et al., 1976a).

This study set out to determine the relationship of this defect of fibrin polymerisation to other indices of hepatocellular function and thus elucidate whether the high fatality observed when associated with bleeding varices is directly caused by the haemorrhagic diathesis or by other aspects of disturbed liver function. The significantly lower serum albumen and raised bilirubin and aspartate aminotransferase in those patients exhibiting defective fibrin polymerisation compared with those patients who did not, all indicate that hepatocellular function is more severely impaired in the former group than in the latter. No difference was noted between the two groups in respect of their alkaline phosphatase and serum globulin levels. However, as neither of these two investigations directly reflects hepatocellular function, this is perhaps understandable.

Fibrinogen is produced exclusively by the liver (Miller and Bale, 1964). However, its level is rarely reduced to below normal in chronic liver disease (Hallén and Nilsson, 1964; Donaldson et al., 1969). The fibrinogen concentration is standardised by dilution before performing the polymerisation test and thus technically does not affect the $\mathrm{H}_{10}$ levels recorded.

We have previously shown that a good correlation exists between the methods of Ingram and Matchett and that of a modified 'Ratnoff and Menzies' technique for estimation of plasma fibrinogen. This correlation does not apply in the presence of abnormal fibrin polymerisation (Green et al., 1976a). However, as none of the patients in this study exhibited raised fibrin(ogen) degradation products, which might also affect the method of fibrinogen estimation here, it is unlikely that this would alter the recorded 
$\mathrm{H}_{10}$ levels significantly. It could, however, contribute to the observed lower mean fibrinogen concentration in the patients with abnormal polymerisation compared with those in the contrast group.

The value of the prothrombin time as an index of liver function is well established. Factor VII, a vitamin K-dependent factor with the shortest plasma half-life, has been of particular prognostic value in acute liver failure (Dymock et al., 1975), but in chronic liver disease is not as reliable (Green et al., 1976b). Factor VII assays and prothrombin times, not surprisingly, showed agreement. The prothrombin time was greatly prolonged and the factor VII assay reduced in the patients with impaired polymerisation compared with the contrast group. This once again supports the observation of more severe impairment of liver function in the former group of patients.

In conclusion, it appears that patients with liver disease exhibiting abnormal fibrin polymerisation have more severely impaired liver function than similarly affected patients who do not have this clotting defect. In cirrhotic patients the combination of abnormal polymerisation and bleeding gastrooesophageal varices is associated with a particularly grave prognosis (Green et al., 1976a). From our findings this could be associated with severely impaired liver function, of which abnormal fibrin polymerisation is one manifestation, rather than with the clotting defect of the dysfibrinogenaemia.

We wish to thank Professor J. M. Evanson for providing clinical facilities, Mr S. R. Armitage for technical assistance, and Dr J. C. Leonard and Mr D. J. Cowley for allowing us to study patients under their care. The work was supported by an MRC programme grant to Dr Leon Poller. We are also grateful to Professor A. G. Redeker for providing the secretarial assistance of Ms Shirlyn $T$. DeBerry.

\section{References}

Aiach, M., Rogé, J., Busy, M. F., Durand, H., Guéroult, N., Chanrion, Ch., Leclerc, M., et Justin-Besançon L. (1973). Dysfibrinogénémies acquises et affections hépatiques. Semaine des Hôpitaux de Paris, 49, 183-197.

Barr, R. D., Ouna, N., Simpson, J. G., and Bagshawe, A. F. (1976). Dysfibrinogenaemia and primary hepato-cellular carcinoma. Quarterly Journal of Medicine, 45, 647-658.

Donaldson, G. W. K., Davies, S. H., Darg, A., and Richmond, J. (1969). Coagulation factors in chronic liver disease. Journal of Clinical Pathology, 22, 199-204.

Dymock, I. W., Tucker, J. S., Woolf, I. L., Poller, L., and Thomson, J. M. (1975). Coagulation studies as a prognostic index in acute liver failure. British Journal of Haematology, 29, 385-395.

Green, G., Thomson, J. M., Poller, L., and Dymock, I. W. (1975). Fibrin monomer polymerization in liver disease (Abstract). Gut, 16, 827.

Green, G., Thomson, J. M., Dymock, I. W., and Poller, L. (1976a). Abnormal fibrin polymerization in liver disease. British Journal of Haematology, 34, 427-439.

Green, G., Poller, L., Thomson, J. M., and Dymock, L. W. (1976b). Factor VII as a marker of hepatocellular synthetic function in liver disease. Journal of Clinical Pathology, 29, 971-975.

Hallén, A., and Nilsson, I. M. (1964). Coagulation studies in liver disease. Thrombosis et Diathesis Haemorrhagica, 11, 51-63.

Ingram, G. I. C., and Matchett, M. O. (1960). A rapid 'side-room' method for the determination of plasma fibrinogen concentration as fibrin. Journal of Clinical Pathology, 13, 469-474.

Miller, L. L., and Bale, W. F. (1954). Synthesis of all plasma protein fractions except gamma globulins by the liver. Journal of Experimental Medicine, 99, 125-132.

Poller, L., Thomson, J. M., Sear, C. H. J., and Thomas, W. (1971). Identification of a congenital defect of Factor VII in a colony of beagle dogs: the clinical use of the plasma. Journal of Clinical Pathology, 24, 626-632.

Soria, J., Soria, C., Yver, J., and Samama, M. (1969). Temps de Reptilase. Étude de la polymérisation de la fibrine en présence de Reptilase. Coagulation, 2, 173-175.

Soria, J., Soria, C., Samama, M., Coupier, J., Girard, M. L., Bousser, J., and Bilski-Pasquier, G. (1970). Dysfibrinogénémies acquisies dans les atteintes hépatiques sévères. Coagulation, 3, 37-44.

Von Felten, A., Straub, P. W., and Frick, P. G. (1969). Dysfibrinogenemia in a patient with primary hepatoma. New England Journal of Medicine, 280, 405-409. 